\title{
Identification and Subgrouping of Cucumber mosaic virus with Mouse Monoclonal Antibodies
}

\author{
H. T. Hsu, L. Barzuna, Y. H. Hsu, W. Bliss, and K. L. Perry
}

First and second authors: Floral and Nursery Plants Research Unit, Agricultural Research Service, United States Department of Agriculture, Beltsville, MD 20705; third author: Institute of Agricultural Sciences, National Chung-Hsing University, Taichung 40227, Taiwan; fourth author: Agdia, Inc., Elkhart, IN 46514; fifth author: Botany and Plant Pathology Department, Purdue University, West Lafayette, IN 47907.

L. Barzuna was a visiting student from the University of Costa Rica.

Accepted for publication 11 February 2000.

\begin{abstract}
Hsu, H. T., Barzuna, L., Hsu, Y. H., Bliss, W., and Perry, K. L. 2000. Identification and subgrouping of Cucumber mosaic virus with mouse monoclonal antibodies. Phytopathology 90:615-620.

Using a mixture of isolates of Cucumber mosaic virus (CMV) from subgroups I and II as immunogens, 20 mouse hybridoma cell lines secreting monoclonal antibodies were produced. A reliable method for efficient detection and accurate subgrouping of CMV isolates has been developed. Tests with 12 well-characterized strains of CMV and other

cucumoviruses demonstrated the presence of epitopes that were virus and subgroup specific. Analyses of 109 accessions of CMV isolates collected from various parts of the world revealed $70 \%$ were subgroup I, with $20 \%$ identified as subgroup II. Seven isolates (6\%) did not react with groupspecific antibodies but did react with antibodies that recognized all CMV isolates. Differential reactions among isolates suggested a total of 10 epitopes were recognized. The antigenic diversity among subgroup II CMVs was greater than for the subgroup I isolates, even though fewer subgroup II isolates were tested.
\end{abstract}

Cucumber mosaic virus (CMV) is the type species of the genus Cucumovirus and is one of the most widespread plant viruses in the world (22). CMV has a very broad host range of wild and cultivated plants, with more than 800 known hosts $(7,22)$. The virus causes diseases and economic losses in cereals, fruits, vegetables, and ornamentals (19). CMV produces a variety of symptoms, the most typical being a mottle or mosaic. Depending on the host and isolate of the virus, the symptoms also may include growth distortion, blight, fan leaf, ringspot, fruit woodiness, and necrosis followed by death of the host plant. Symptoms incited by CMV can be affected by the presence of satellite RNA (22), e.g., by the CMV-associated RNA5 (CARNA5) $(18,30)$. Diseases caused by CMV have been confused with those caused by other viruses, and in some cases, CMV does not induce obvious symptoms $(3,26)$. The natural spread of CMV is primarily by aphid vectors (9). Seed transmission of CMV is also a significant means of transmission in some weeds and cultivated crop plants (19). Weed hosts function as a reservoir for the virus and serve as sources of inoculum in the regional development of disease epidemics (26).

Serological studies of CMV have shown this species to be antigenically heterogeneous (4-6). CMV isolates were originally characterized as belonging to one of two serological groups (4), although a third serogroup has been reported (6). The serogroup concept subsequently was broadened based on hybridization analyses using complementary DNAs $(11,21,24)$. Although the terms subgroup and serogroup have routinely been used interchangeably, a serogroup designation is based on antigenicity and the subgroup

Corresponding author: H. T. Hsu, E-mail address: hhsu@ asrr.arsusda.gov

Mention of a trade name, proprietary product, or specific equipment or vendor does not constitute a guarantee or warranty by the USDA and does not imply approval to the exclusion of other products or vendors that may also be suitable.

Publication no. P-2000-0330-03R

This article is in the public domain and not copyrightable. It may be freely reprinted with customary crediting of the source. The American Phytopathological Society, 2000. is inferred. Complications result in the case of some unique viruses that are naturally occurring reassortants of two cucumoviruses or strains (31).

The serological differentiation of CMV isolates is of importance in breeding for disease resistance and in studying disease epidemiology, so specific monoclonal antibodies have been developed $(1,12,25,26)$. One of the goals in their development was to provide tools for serotyping isolates of the virus. Monoclonal antibodies with serotype specificity were described $(12,25)$, but they were tested only with a limited number of strains and, in some cases, did not recognize all members within a subgroup. The objectives of this study were to obtain monoclonal antibodies that are subgroup specific and to test a representative collection of worldwide isolates to validate the utility of the antibodies for serological classification. In this article, we report the establishment of somatic cell hybrids that secrete monoclonal antibodies to $\mathrm{CMV}$ and present an analysis of their potential for use in the serotyping of CMV.

\section{MATERIALS AND METHODS}

Viruses and antigens. The CMV isolates used were from Agdia, Inc. (Elkhart, IN), the American Type Culture Collection (ATCC; Manassas, VA), L. Barnes (Texas A\&M University, College Station), T. Day (Sakata Seed America, Inc., Salinas, CA), J. Fletcher (Crop and Food Research, Christchurch, New Zealand), R. W. Goth (U.S. Department of Agriculture-Agricultural Research Service [USDAARS], Beltsville, MD), S. K. Green (Asian Vegetable Research and Development Center, Tainan, Taiwan), J. M. Kaper (USDAARS, Beltsville, MD), X. P. Liu (Heilongjiang Academy of Agricultural Sciences, Harbin, China), A. Stein (Agricultural Research Organization, The Volcani Center, Bet Dagan, Israel), and the authors (Table 1). The E isolate of Peanut stunt virus (PSV) and the V strain of Tomato aspermy virus (TAV) were from the Purdue University collection, and PSV isolate IZ9101 was obtained from J. Staniulis (Botanikos Institutas, Vilnius, Lithuania). Virions of the following were purified and used as immunogens: CMV isolates S, D, Price's 6, NT9, BCM, GC1, GCM, CR M-1, and CR P-1. 
TABLE 1. Sources of Cucumber mosaic virus isolates and their contributors

\begin{tabular}{|c|c|c|c|c|c|c|c|}
\hline Isolate & Origin & Location & Contributor $^{\mathrm{a}}$ & Isolate & Origin & Location & Contributor $^{\mathrm{a}}$ \\
\hline A7410 & & & Agdia & P1018 & Pepper & Taiwan & Green \\
\hline C310 (N890) & Gladiolus & Georgia & Agdia & P1347 & Pepper & Taiwan & Green \\
\hline $\mathrm{C} 105$ & Pepper & Michigan & Agdia & P1360 & Pepper & Taiwan & Green \\
\hline C109 & Tomato & California & Agdia & P1369 & Pepper & Taiwan & Green \\
\hline C107 & Cucurbit & Indiana & Agdia & P1370 & Pepper & Taiwan & Green \\
\hline C296 & Cucurbit & Arizona & Agdia & P1441 & Pepper & Taiwan & Green \\
\hline C297 & Cucurbit & Arizona & Agdia & P1471 & Pepper & Taiwan & Green \\
\hline M426 & Pepper & Indiana & Agdia & P1624 & Pepper & Taiwan & Green \\
\hline O69 & Orchid & Florida & Agdia & P1628 & Pepper & Taiwan & Green \\
\hline P922 & & USDA & Agdia & P1886 & Pepper & Taiwan & Green \\
\hline Watercress & Watercress & & Agdia & P1927 & Pepper & Taiwan & Green \\
\hline PV 29 Tyре 1 & Cucumber & Wisconsin & ATCC & P1929 & Pepper & Taiwan & Green \\
\hline PV 30 CD & Commelina nudiflora & Maryland & ATCC & P2469 & Pepper & Taiwan & Green \\
\hline PV 59 & Sugar beet & Arizona & ATCC & P2853 & Pepper & Taiwan & Green \\
\hline PV 242 & & Maryland & ATCC & P2874 & Pepper & Taiwan & Green \\
\hline PV 243 & Mung bean & Missouri & ATCC & P2875 & Pepper & Taiwan & Green \\
\hline PV 289 Q & & Australia & ATCC & P2878 & Pepper & Taiwan & Green \\
\hline PV $453 \mathrm{C}$ & Pepper & California & ATCC & Peet & Tomato & Taiwan & Green \\
\hline PV 539 Py & & California & ATCC & RS12 & Tomato & Taiwan & Green \\
\hline PV $540 \mathrm{Y}$ & & Ibaraki, Japan & ATCC & $\mathrm{T} 2373$ & Tomato & Taiwan & Green \\
\hline PV 542 LS & & New York & ATCC & $\mathrm{T} 2374$ & Tomato & Taiwan & Green \\
\hline PV $543 \mathrm{O}$ & & Japan & ATCC & BCM & Banana & Taiwan & Hsu \\
\hline PV 544 PY & & New Jersey & ATCC & GC1 & Gladiolus & Taiwan & $\mathrm{Hsu}$ \\
\hline PV 545 P6 & & New Jersey & ATCC & GCM & Gladiolus & Taiwan & Hsu \\
\hline PV 546 M & & Cambridge, UK & ATCC & 1 & & United States & Kaper \\
\hline PV 547 Sny & & New York & ATCC & 16 & & Japan & Kaper \\
\hline PV 548 Fny & & New York & ATCC & ICS & & Indonesia & Kaper \\
\hline PV 549 CMV-48 & & & ATCC & Ixora & & Philippines & Kaper \\
\hline PV634 K8 & Cucumis metuliferus & Piedmont, Italy & ATCC & $\mathrm{D}$ & & France & Kaper \\
\hline S390 & Ajuga sp. & Texas & Barnes & $\mathrm{R}$ & & France & Kaper \\
\hline CR M-1 & Melon & Costa Rica & Barzuna & R76B & & England & Kaper \\
\hline CR P-1 & Plantain & Costa Rica & Barzuna & $\mathrm{Rm}$ & & France & Kaper \\
\hline $\mathrm{T} 118$ & Impatiens & Japan & Day & $\mathrm{S}$ & & South Africa & Kaper \\
\hline F354 Seed & & & & & & & \\
\hline $\begin{array}{l}\text { transmissible } \\
\text { \#4 Not seed }\end{array}$ & Spinach & California & Day & Peet & & Taiwan & Kaper \\
\hline transmissible & Spinach & California & Day & RS15 & & Taiwan & Kaper \\
\hline 88 & Pepper & New Zealand & Fletcher & $\mathrm{Y}$ & Tobacco & Japan & Kaper \\
\hline 90 & Lentil & New Zealand & Fletcher & \#2 & & China & Liu \\
\hline 94 & Scotch thistle & New Zealand & Fletcher & \#3 & & China & Liu \\
\hline 97 & Tomato & New Zealand & Fletcher & \#5 & & China & Liu \\
\hline 98 & Spinach & New Zealand & Fletcher & $\# 10$ & & China & Liu \\
\hline 100 & Pepper & New Zealand & Fletcher & \#11 & & China & Liu \\
\hline 101 & Tomato & New Zealand & Fletcher & \#12 & & China & Liu \\
\hline 107 & Pepper & New Zealand & Fletcher & \#14 & & China & Liu \\
\hline 110 & Lettuce & New Zealand & Fletcher & Fny & Muskmelon & New York & Perry \\
\hline 116 & Gentiana sp. & New Zealand & Fletcher & Sny & Muskmelon & New York & Perry \\
\hline 119 & Pea & New Zealand & Fletcher & $\mathrm{T}$ & Pepper & Western Australia & Perry \\
\hline 223 & Myoga ginger & New Zealand & Fletcher & $\mathrm{O}$ & Lupin & Queensland, Australia & Perry \\
\hline WT & & Wisconsin & Goth & Q & Pepper & Queensland, Australia & Perry \\
\hline$\# 1,10 / 26 / 63$ & Tobacco & United States & Goth & LS & Lettuce & New York & Perry \\
\hline F10 & Tomato & Taiwan & Green & $\mathrm{U}$ & Banana & Queensland, Australia & Perry \\
\hline M48 & Mung bean & Taiwan & Green & $\mathrm{T}_{1} \mathrm{~T}_{2} \mathrm{Q}_{3}$ & $\begin{array}{l}\text { Reassortant with isolate } \\
\text { CMV-Q RNA } 3\end{array}$ & & Perry \\
\hline NT4 & Tomato & Taiwan & Green & M & Mutant of Price's 6 & & Perry \\
\hline NT9 & Tomato & Taiwan & Green & V135 & & & Perry \\
\hline P3 & Pepper & Taiwan & Green & $\mathrm{F}_{1} \mathrm{~F}_{2} \mathrm{M}_{3}$ & $\begin{array}{l}\text { Reassortant with isolate } \\
\text { CMV-M RNA } 3\end{array}$ & & Perry \\
\hline P117 & Pepper & Taiwan & Green & V389 & & Italy & Perry \\
\hline P184 & Pepper & Taiwan & Green & N-1A & Squash & New York & Perry \\
\hline P212 & Pepper & Taiwan & Green & N-1B & Squash & New York & Perry \\
\hline P427 & Pepper & Taiwan & Green & Ala1 & Tomato & Alabama & Perry \\
\hline P522 & Pepper & Taiwan & Green & Ala3 & Tomato & Alabama & Perry \\
\hline P600 & Pepper & Taiwan & Green & Mal1 & & USA & Perry \\
\hline P652 & Pepper & Taiwan & Green & $1 \mathrm{~A} 1$ & Pepper & Illinois & Perry \\
\hline P661 & Pepper & Taiwan & Green & $2 \mathrm{~A} 1$ & Pepper & Illinois & Perry \\
\hline P888 & Pepper & Taiwan & Green & S2A & Squash & New York & Perry \\
\hline P959 & Pepper & Taiwan & Green & Price's 6 & & New Jersey & Stein \\
\hline
\end{tabular}

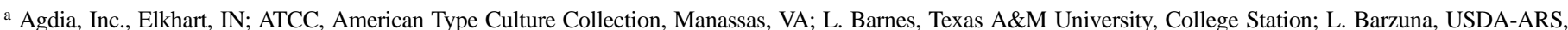
Beltsville, MD; T. Day, Sakata Seed America, Inc., Salinas, CA; J. Fletcher, Crop and Food Research, Christchurch, New Zealand; R. W. Goth, USDA-ARS; S. K. Green, Asian Vegetable Research and Development Center, Tainan, Taiwan; H. T. Hsu, USDA-ARS; J. M. Kaper, USDA-ARS; X. P. Liu, Heilongjiang Academy of Agricultural Sciences, Harbin, China; K. L. Perry, Agdia, Inc.; A. Stein, Agricultural Research Organization, The Volcani Center, Bet Dagan, Israel. 
Purified preparations of the S and D isolates were gifts from J. M. Kaper. All other isolates were purified from inoculated squash, as described by Hsu et al. (17). Previously characterized subgroup I isolates D, Fny, M, O, Sny, Y, and T and subgroup II isolates LS, $\mathrm{Q}, \mathrm{S}, \mathrm{U}$, and $\mathrm{R}(21,25,29)$ were used for initial characterization of monoclonal antibody recognition specificity.

Immunization. A mixture of equal amounts of the nine purified viruses was used for immunization of mice. Three BALB/c female mice were each injected with a total of $100 \mu \mathrm{g}$ of purified virus according to an immunization schedule previously described (15). Five days after the fourth injection, mice were given a peritoneal injection of $200 \mu \mathrm{g}$ of purified virus in $0.2 \mathrm{ml}$ of phosphate-buffered saline solution (PBS; $0.01 \mathrm{M}$ phosphate and $0.015 \mathrm{M}$ sodium chloride, $\mathrm{pH}$ 7.5). Mice were sacrificed 3 days later, and their spleens were harvested.

Fusion and selection. Single splenocyte suspensions were prepared from immune spleens and fused with FOX-NY myeloma cells, as described previously (14). After fusion, cells were resuspended and cultured in a FOX-NY-conditioned medium (nine parts of complete RPMI-1640 medium and one part of myeloma cellconditioned medium) supplemented with $10^{-1} \mathrm{mM}$ hypoxanthine, $4 \times 10^{-4} \mathrm{mM}$ aminopterin, $1.6 \times 10^{-2} \mathrm{mM}$ thymidine, $6 \mathrm{mM}$ Hepes, and $2 \times 10^{-2} \mathrm{mM} 2$-mercaptoethanol, and seeded in 96-well culture plates $(16)$. Twice a week, $\approx 100 \mu$ l of culture medium was replaced with a similar amount of the same fresh medium. Two weeks after fusion, aminopterin was omitted from the medium.

Monoclonal antibodies. Two types of enzyme-linked immunosorbent assays (ELISA) were used for identification of hybridomas secreting antibodies specific to CMV (15). In one procedure, coating antibody solutions $(2 \mu \mathrm{g} / \mathrm{ml})$ were prepared by mixing equal amounts of polyclonal antisera prepared against CMV-D (subgroup I) and CMV-S (subgroup II). Mixtures of each antigen used for immunization $(1 \mu \mathrm{g} / \mathrm{ml})$ were prepared in PBS and incubated in antibody-coated wells before the culture medium was added to each well. The second procedure involved sensitizing ELISA plates with the same mixture of antigens prepared in $0.1 \mathrm{M}$ carbonate coating buffer at $\mathrm{pH}$ 9.6. Alkaline phosphatase-labeled goat antimouse immunoglobulins were used to detect mouse antibodies in both procedures. A double-antibody sandwich (DAS)-ELISA employing purified rabbit antibodies (mixture of equal amounts of $1 \mu \mathrm{g}$ each of anti-CMV-D and anti-CMV-S per ml) and homologous enzyme conjugates was used as a control. Immunoglobulin class was determined with commercial isotyping kits (Sigma-Aldrich Chemical Co., St Louis). Single-cell clonings were similar to those previously described, except that FOX-NY-conditioned medium was used (14). Large-scale production of monoclonal antibodies in ascitic fluids was done by Cocalico Biological Co. (Streamtown, PA).

Antibody specificities and CMV serotyping. Antibodies were titered by DAS-ELISA, using horseradish peroxidase (HRP)-immunoglobulin conjugates. Individual antibody concentrations that gave between 1.5 and 2.0 absorbance (492 nm) values $15 \mathrm{~min}$ after addition of substrate were determined and used in triple-antibody sandwich (TAS)-ELISA (Table 2) for determination of reactivities of mouse monoclonal antibodies to CMV isolates. The polyclonal antisera for CMV, PSV, and TAV were from Agdia. ELISA plates were coated with a mixture of equal amounts of rabbit immunoglobulins prepared against CMV-D and CMV-S. Individual viral antigens were prepared from fresh leaf tissues $(1: 10$, $\mathrm{wt} / \mathrm{vol})$ or dried leaf tissue $(1: 100, \mathrm{wt} / \mathrm{vol})$ by grinding in a mortar and pestle with Agdia extraction buffers. Purified virus was diluted to $200 \mathrm{ng} / \mathrm{ml}$ in the same extraction buffer. After the addition of individually optimized monoclonal antibodies (Table 2) to the plates, HRP-labeled rabbit antimouse immunoglobulin antibodies $(0.3 \mu \mathrm{g} / \mathrm{ml})$ in DeMan-Rogosa-Sharpe (MRS) buffer (Agdia) were immediately added and incubated together with the monoclonal antibodies. Phenylenediamine dihydrochloride at $0.1 \mathrm{mg} / \mathrm{ml}$ in a hydrogen peroxide solution, $\mathrm{pH}$ 5.0, was used as substrate. Heal- thy tobacco plants, plants infected with Potato A virus (PVA), and buffer alone were used as controls. All tests were duplicated. Reagents were used (100 $\mu$ l per test well) in Nunc Maxisorp microtiter plates (A/S Nunc, Roskilde, Denmark).

\section{RESULTS}

Twenty mouse hybridoma cell lines secreting monoclonal antibodies to CMV were established, and the immunoglobulin classes and subclasses for each were determined (Table 2). The antibodies were produced in ascitic fluids in mice, and the optimum dilution of the antibody solutions for use in ELISA ranged from 1:1,000 to 1:32,000 (Table 2).

In testing the recognition specificity of the monoclonal antibodies, a DAS-ELISA was used as a reference in all assays. This used a mixture of polyclonal rabbit antisera prepared to CMV-D (subgroup I) and CMV-S (subgroup II), and these polyclonal antibodies detected all strains of CMV in both subgroups (Tables 3 and 4). In TAS-ELISA, assays with extracts from control plants, either healthy or PVA infected, yielded optical density $\left(492 \mathrm{~nm}\right.$; $\mathrm{OD}_{492 \mathrm{~nm}}$ ) readings in the range of 0.029 to 0.072 . Scores of 2 indicate absorbance values $>0.4$, and scores of 1 indicate absorbance values ranging from 0.1 to 0.4 . Absorbance values $<0.1$ were scored as 0 .

Monoclonal antibodies, when tested with 12 well-characterized CMV isolates, could be assigned to three major categories based on their specificities (Table 3). Three monoclonal antibodies (4H10B6, 4H10B12, and 6D11B9) reacted with all members of CMV in subgroup I but did not react with CMV strains in subgroup II. Four monoclonal antibodies (6D11D12, 7B3D3, 7B3D9, and 60B3E7) reacted with CMV strains in subgroup II but did not react with CMV in subgroup I, although 60B3E7 failed to recognize one of the subgroup II strains. A number of the monoclonal antibodies reacted with all 12 isolates from both subgroups; the 3 strongest reactions strongly (10F10F9, 44E9A7, and 62B7A3) are indicated in Table 3. Antigenic variations were apparent among members of CMV in subgroup II; fewer variations were observed in subgroup I.

To establish the general applicability of the monoclonal antibodies, a variety of CMV isolates from worldwide collections were tested. Most of the CMV isolates from culture collections were previously uncharacterized, but others have been well studied. Some isolates may be duplicates and were maintained independently in the different collections. Approximately $70 \%$ of the isolates (76/109) were assigned to subgroup I, whereas 20\% (22/109) of the isolates were identified as subgroup II (Table 4). All isolates of CMV in

TABLE 2. Cucumber mosaic virus antibodies, immunoglobulin (Ig) classes and subclasses of monoclonal antibodies, and dilutions of ascitic fluids used in the study

\begin{tabular}{llc}
\hline Antibody & Class and subclass & Optimum dilution \\
\hline Polyclonal & & $1 / 1,300$ \\
10F10F9 & IgG1 & $1 / 16,000$ \\
44E9A7 & IgM & $1 / 32,000$ \\
62B7A3 & IgG2a & $1 / 4,000$ \\
23C10E4 & IgG1 & $1 / 4,000$ \\
34H11C10 & IgG1 & $1 / 16,000$ \\
6G6B4 & IgG1 & $1 / 4,000$ \\
9D11F11 & IgG1 & $1 / 4,000$ \\
15E6F2 & IgG1 & $1 / 4,000$ \\
42G5D3 & IgM & $1 / 16,000$ \\
14C5A4 & IgG2a & $1 / 32,000$ \\
44E4B7 & IgG2a & $1 / 16,000$ \\
14D12H9 & IgG2a & $1 / 16,000$ \\
46D12B12 & IgM & $1 / 1,000$ \\
4H10B6 & IgG1 & $1 / 8,000$ \\
4H10B12 & IgG1 & $1 / 32,000$ \\
6D11B9 & IgG1 & $1 / 32,000$ \\
6D11D12 & IgG1 & $1 / 16,000$ \\
7B3D3 & IgG1 & $1 / 8,000$ \\
7B3D9 & IgG1 & $1 / 1,000$ \\
60B3E7 & IgM & $1 / 16,000$ \\
\hline
\end{tabular}


the our study tested positively in TAS-ELISA with monoclonal antibodies 10F10F9, 44E9A7, and 62B7A3 (Table 4). All of the monoclonal antibodies also were tested for their recognition of TAV and PSV, and, with one exception, results were negative, and ELISA values were comparable to those of the controls. The exception was antibody 62B7A3, which reacted weakly with TAV and recognized one of the two PSV isolates (Table 4). Seven CMV isolates (C296, M48, PV243, PV634, M426, \#4 not seed transmis- sible, and 116) were unique in that they were not recognized by either subgroup I- or subgroup II-specific monoclonal antibodies (Table 4). These unique isolates tested negative for TAV and PSV in DAS-ELISA with polyclonal rabbit antisera, with the exception of \#4 not seed transmissible, which was not available in sufficient quantity for additional testing. Four CMV isolates (S2A, C105, Mal1, and C109) reacted with both subgroup I- and subgroup II-specific antibodies, although in each case reactions with one of the two

TABLE 3. Reactions of monoclonal antibodies to previously characterized strains of Cucumber mosaic virus (CMV) of known subgroup ${ }^{\mathrm{a}}$

\begin{tabular}{|c|c|c|c|c|c|c|c|c|}
\hline \multirow[b]{2}{*}{ Cell line or antibody } & \multicolumn{3}{|c|}{ CMV subgroup I } & \multicolumn{5}{|c|}{ CMV subgroup II } \\
\hline & $\mathrm{D}^{\mathrm{b}}$ & Fny $^{\mathrm{c}}$ & $\mathrm{M}$ & LS & $\mathrm{Q}$ & $\mathrm{S}$ & $\bar{U}$ & $\mathrm{R}$ \\
\hline Polyclonal & 2 & 2 & 2 & 2 & 2 & 2 & 2 & 2 \\
\hline 10F10F9 & 2 & 2 & 2 & 2 & 2 & 2 & 2 & 2 \\
\hline 44E9A7 & 2 & 2 & 2 & 2 & 2 & 2 & 2 & 2 \\
\hline $62 \mathrm{~B} 7 \mathrm{~A} 3$ & 2 & 2 & 2 & 2 & 2 & 2 & 2 & 2 \\
\hline $23 \mathrm{C} 10 \mathrm{E} 4$ & 2 & 1 & 2 & 2 & 2 & 2 & 2 & 2 \\
\hline $34 \mathrm{H} 11 \mathrm{C} 10$ & 2 & 2 & 2 & 2 & 2 & 2 & 2 & 0 \\
\hline 6G6B4 & 2 & 2 & 1 & 2 & 1 & 2 & 1 & 2 \\
\hline 9D11F11 & 2 & 2 & 1 & 2 & 1 & 2 & 1 & 2 \\
\hline $15 \mathrm{E} 6 \mathrm{~F} 2$ & 2 & 2 & 1 & 2 & 1 & 2 & 1 & 2 \\
\hline 42G5D3 & 2 & 2 & 2 & 1 & 2 & 2 & 1 & 1 \\
\hline $14 \mathrm{C} 5 \mathrm{~A} 4$ & 2 & 2 & 2 & 2 & 2 & 1 & 0 & 0 \\
\hline 44E4B7 & 2 & 2 & 2 & 2 & 2 & 1 & 0 & 0 \\
\hline 14D12H9 & 2 & 2 & 2 & 2 & 2 & 1 & 0 & 0 \\
\hline 46D12B12 & 2 & 2 & 1 & 2 & 2 & 0 & 0 & 0 \\
\hline $4 \mathrm{H} 10 \mathrm{~B} 6$ & 2 & 2 & 2 & 0 & 0 & 0 & 0 & 0 \\
\hline $4 \mathrm{H} 10 \mathrm{~B} 12$ & 2 & 2 & 2 & 0 & 0 & 0 & 0 & 0 \\
\hline 6D11B9 & 2 & 2 & 2 & 0 & 0 & 0 & 0 & 0 \\
\hline 6D11D12 & 0 & 0 & 0 & 2 & 2 & 2 & 2 & 2 \\
\hline 7B3D3 & 0 & 0 & 0 & 2 & 2 & 2 & 2 & 2 \\
\hline 7B3D9 & 0 & 0 & 0 & 2 & 2 & 2 & 2 & 2 \\
\hline $60 \mathrm{~B} 3 \mathrm{E} 7$ & 0 & 0 & 0 & 0 & 1 & 2 & 1 & 1 \\
\hline
\end{tabular}

${ }^{a}$ Enzyme-linked immunosorbent assay reactions were scored as 2 for measurements greater than $0.4 ; 1$ for measurements of 0.1 to 0.4 ; and 0 for measurements less than 0.1 . The optical density for buffer wells ranged from 0.009 to 0.070 . The optical density for healthy or Potato A virus-infected tobacco ranged from 0.029 to 0.072 . Reactions that are virus or subgroup specific are boxed.

b Strains O, Sny, and Y produced results similar to strain D.

c Strain T produced results similar to strain Fny.

TABLE 4. Reactions of monoclonal antibodies to Cucumber mosaic virus isolates from various collections and designation of proposed recognized epitopes (PE) ${ }^{\mathrm{a}}$

Cucumber mosaic virus isolate

Cell line F354 \#4

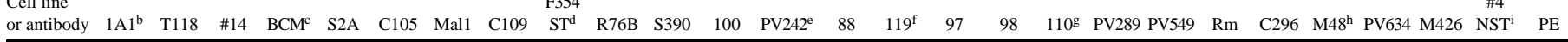

\begin{tabular}{|c|c|c|c|c|c|c|c|c|c|c|c|c|c|c|c|c|c|c|c|c|c|c|c|c|c|c|}
\hline Polyclonal & 2 & 2 & 2 & 2 & 2 & 2 & 2 & 2 & 2 & 2 & 2 & 2 & 2 & 2 & 2 & 2 & 2 & 2 & 2 & 1 & 1 & 2 & 2 & 2 & 2 & 2 \\
\hline 10F10F9 & 2 & 2 & 2 & 2 & 2 & 2 & 2 & 2 & 2 & 2 & 2 & 2 & 2 & 2 & 2 & 2 & 2 & 2 & 2 & 2 & 2 & 2 & 2 & 2 & 2 & 2 \\
\hline 44E9A7 & 2 & 2 & 2 & 2 & 2 & 2 & 2 & 2 & 2 & 2 & 2 & 2 & 2 & 2 & 2 & 2 & 2 & 2 & 2 & 2 & 2 & 2 & 2 & 2 & 2 & 2 \\
\hline $62 \mathrm{~B}^{2} \mathrm{~A}^{\mathrm{j}}$ & 2 & 2 & 2 & 2 & 2 & 2 & 2 & 2 & 2 & 2 & 2 & 2 & 2 & 2 & 2 & 2 & 2 & 2 & 2 & 2 & 1 & 2 & 1 & 2 & 2 & 2 \\
\hline 23C10E4 & 1 & 0 & 1 & 2 & 2 & 2 & 2 & 2 & 2 & 2 & 0 & 2 & 2 & 2 & 2 & 2 & 1 & 1 & 1 & 2 & 2 & 2 & 0 & 1 & 1 & 0 \\
\hline $34 \mathrm{H} 11 \mathrm{C} 10$ & 2 & 2 & 2 & 1 & 2 & 2 & 2 & 2 & 2 & 2 & 2 & 2 & 1 & 2 & 2 & 0 & 1 & 1 & 1 & 1 & 0 & 2 & 1 & 2 & 2 & 1 \\
\hline 6G6B4 & 2 & 1 & 1 & 0 & 2 & 2 & 2 & 1 & 2 & 1 & 1 & 2 & 1 & 1 & 1 & 1 & 1 & 0 & 1 & 0 & 0 & 2 & 1 & 0 & 0 & 0 \\
\hline 9D11F11 & 2 & 1 & 1 & 0 & 2 & 2 & 2 & 2 & 2 & 1 & 1 & 1 & 1 & 1 & 1 & 1 & 0 & 0 & 1 & 0 & 0 & 2 & 1 & 0 & 0 & 0 \\
\hline 15E6F2 & 2 & 1 & 0 & 0 & 2 & 2 & 2 & 1 & 2 & 1 & 1 & 2 & 1 & 2 & 1 & 1 & 1 & 0 & 1 & 0 & 0 & 2 & 1 & 0 & 0 & 0 \\
\hline 42G5D3 & 2 & 2 & 2 & 2 & 2 & 2 & 1 & 1 & 2 & 1 & 1 & 2 & 0 & 2 & 2 & 2 & 1 & 1 & 0 & 0 & 0 & 0 & 0 & 0 & 0 & 1 \\
\hline $14 \mathrm{C} 5 \mathrm{~A} 4$ & 2 & 2 & 2 & 1 & 2 & 2 & 2 & 2 & 2 & 1 & 2 & 1 & 1 & 1 & 0 & 0 & 0 & 0 & 0 & 0 & 0 & 2 & 1 & 2 & 0 & 0 \\
\hline 44E4B7 & 2 & 2 & 2 & 1 & 2 & 2 & 2 & 2 & 2 & 1 & 2 & 1 & 1 & 1 & 0 & 0 & 0 & 0 & 0 & 0 & 0 & 2 & 1 & 2 & 0 & 0 \\
\hline 14D12H9 & 2 & 2 & 2 & 1 & 2 & 2 & 2 & 2 & 2 & 1 & 2 & 1 & 1 & 0 & 0 & 0 & 0 & 0 & 0 & 0 & 0 & 2 & 1 & 2 & 0 & 0 \\
\hline 46D12B12 & 2 & 2 & 1 & 1 & 2 & 2 & 1 & 1 & 2 & 1 & 2 & 0 & 0 & 0 & 0 & 0 & 0 & 0 & 0 & 0 & 0 & 2 & 1 & 1 & 1 & 0 \\
\hline 4H10B6 & 2 & 2 & 2 & 2 & 2 & 2 & 1 & 1 & 0 & 0 & 0 & 0 & 0 & 0 & 0 & 0 & 0 & 0 & 0 & 0 & 0 & 0 & 0 & 0 & 0 & 0 \\
\hline 4H10B12 & 2 & 2 & 2 & 1 & 2 & 2 & 1 & 1 & 0 & 0 & 0 & 0 & 0 & 0 & 0 & 0 & 0 & 0 & 0 & 0 & 0 & 0 & 0 & 0 & 0 & 0 \\
\hline 6D11B9 & 2 & 2 & 2 & 1 & 2 & 2 & 1 & 1 & 0 & 0 & 0 & 0 & 0 & 0 & 0 & 0 & 0 & 0 & 0 & 0 & 0 & 0 & 0 & 0 & 0 & 0 \\
\hline 6D11D12 & 0 & 0 & 0 & 0 & 1 & 1 & 2 & 2 & 2 & 2 & 2 & 2 & 2 & 2 & 2 & 2 & 1 & 1 & 1 & 1 & 1 & 0 & 0 & 0 & 0 & 0 \\
\hline 7B3D3 & 0 & 0 & 0 & 0 & 1 & 1 & 2 & 2 & 2 & 2 & 2 & 2 & 2 & 2 & 2 & 2 & 1 & 1 & 1 & 1 & 1 & 0 & 0 & 0 & 0 & 0 \\
\hline 7B3D9 & 0 & 0 & 0 & 0 & 1 & 1 & 2 & 2 & 2 & 2 & 2 & 2 & 2 & 2 & 2 & 2 & 1 & 1 & 1 & 1 & 1 & 0 & 0 & 0 & 0 & 0 \\
\hline 60B3E7 & 0 & 0 & 0 & 0 & 1 & 0 & 0 & 0 & 0 & 1 & 1 & 0 & 0 & 0 & 0 & 0 & 0 & 0 & 0 & 0 & 1 & 0 & 0 & 0 & 0 & 0 \\
\hline
\end{tabular}

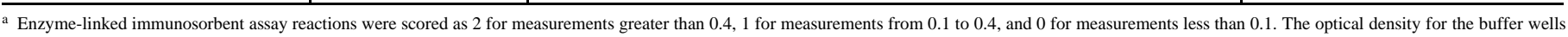
ranged from 0.009 to 0.070 . The optical density for healthy and Potato A virus-infected tobacco ranged from 0.029 to 0.072 . Reactions that are virus or subgroup specific are boxed.

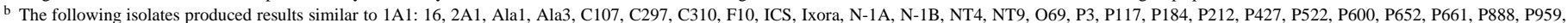
P1018, P1347, P1360, P1369, P1370, P1441, P1471, P1624, P1628, P1886, P1927, P1929, P2469, P2853, P2874, P2875, P2878, Peet, RS12, T2373, T2374, Tobacco \#1, V135, F F $\mathrm{M}_{3}, \mathrm{~V} 389$, \#2, \#3, \#5, \#10, \#11, \#12, PV29, PV30, PV59, PV453, PV539, PV540, PV543, PV544, PV545, PV546, PV547, PV548, WT, and A7410.

c CMV P922 produced results similar to BCM.

${ }^{d}$ Samples $\mathrm{T}_{1} \mathrm{~T}_{2} \mathrm{Q}_{3}$, RS15, and 107 produced results similar to F354 ST (seed transmissible).

e PV542 produced results similar to PV242.

f Samples Watercress, 94, 101, and 90 produced results similar to 119.

g Sample 223 produced results similar to 110 .

h PV243 produced results similar to M48.

i Sample 116 produced results similar to \#4 NST (not seed transmissible).

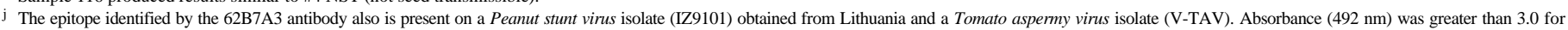
IZ9101 and averaged 0.126 for V-TAV. 
types of subgroup-specific antibodies were relatively weak (Table 4). The absorbance values for $\mathrm{S} 2 \mathrm{~A}$ and $\mathrm{C} 105$ tested with the subgroup Ispecific antibodies were $>3.0$, whereas the values with the subgroup II-specific antibodies were always $<0.2$ (data not shown). On the other hand, absorbance values of Mal1 and C109 with subgroup Ispecific antibodies were generally $<0.2$, whereas the subgroup IIspecific antibodies were between 1.6 and 3.0 (data not shown).

\section{DISCUSSION}

Results obtained in tests of all 121 strains and isolates revealed patterns that suggest there are at least 10 epitopes on virions of CMV (Table 4). These epitopes are inferred by the observation that subsets of the monoclonal antibodies recognized the same isolates, usually with similar intensities of signals. For instance, the first two monoclonal antibodies listed in Table 4, 10F10F9 and 44E9A7, reacted with every isolate of CMV tested and are hypothesized as recognizing the same epitope, designated epitope 1 . The third antibody, 62B7A3, had a similar pattern, but it also reacted with a TAV and PSV isolate; therefore, its recognized epitope is designated epitope 2. Other antibodies recognized different subsets of the collection of isolates, and their recognized epitopes are designated 3 through 10 . The three monoclonal antibodies that are subgroup I-specific are thought to recognize the same epitope (epitope 8). Similarly, the epitope unique to the subgroup II strains is designated epitope 9 . The antibody 60B3E7 is subgroup II specific, but it recognized only a small number of subgroup II isolates; therefore, its epitope is given a separate designation, epitope 10. Interestingly, at least a part of epitope 3 recognized by monoclonal antibody $23 \mathrm{C} 10 \mathrm{E} 4$ has been identified. It is a linear sequence of at least six coat protein-specific amino acids sufficient to confer binding (13).

Analyses of antibody reactivity of a large number of isolates in this study have identified those whose coat proteins appear to be different from the majority. The four isolates that are recognized by both subgroup I- and subgroup II-specific antibodies appear to be unique, although it is possible that these isolates originated from infections with a mixture of CMV strains belonging to both subgroups; mixed infections are not uncommon in natural populations of CMV (10,23). Other examples would be the seven isolates that are not recognized by either set of the subgroup-specific antibodies. It would be of interest to see if the sequencing of these coat protein genes revealed common changes at the positions of otherwise highly conserved amino acids.

A variety of properties have been used to group CMV isolates into two major subgroups, including antigenic specificity, symptomatology, peptide mapping, and nucleic acid analyses $(2,8,20$, $21,24,29)$. A recent example of these methods is the development of reverse transcriptase-polymerase chain reaction-based assays (27, 28). Although serological methods facilitate the rapid processing of large numbers of samples, they suffer from the drawback of analyzing, via the encoded coat protein, only a small portion of the viral genome. In our study, the identification of virus subgroup using serological methods has yielded results consistent with those obtained by analyses of the entire genome. This indicates that these monoclonal antibodies can be used reliably to type a majority of CMV isolates to a subgroup. Furthermore, two of the antibodies recognize all CMV isolates tested but do not cross react with other cucumoviruses. Given the number of isolates used in this study, it is expected that these virus- and subgroup-specific monoclonal antibodies will be generally applicable in both diagnostic work and epidemiological studies.

\section{ACKNOWLEDGMENTS}

We thank L. Barnes, T. Day, J. Fletcher, R. Goth, S. Green, J. M Kaper, X. P. Liu, J. Staniulis, and A. Stein for providing CMV isolates from their collections.

\section{LITERATURE CITED}

1. Ambrosova, S. M., Kirrilov, A. V., Soukhatchova, E. A., Bobkova, A. F., Natsvlishvili, N. M., Malofeyeva, Y. S., and Atabekov, I. G. 1992. A monoclonal immunoenzymatic test system for the cucumber mosaic virus detection. Bioorg. Khim. 18:1089-1097.

2. Anderson, B. J., Boyce, P. M., and Blanchard, C. L. 1995. RNA 4 sequences from cucumber mosaic virus subgroups I and II. Gene 161:293294.

3. Choi, J. K., Kim, H. J., Hong, J. S., Kim, D. W., and Lee, S. Y. 1998. Identification and differentiation of cucumber mosaic isolates in Korea. Kor. J. Plant Pathol. 14:7-12.

4. Devergne, J. C., and Cardin, L. 1973. Contribution a l'étude du virus de la mosaique du concombre (CMV). IV. Essai de classification de plusieurs isolats sur la base de leur structure antigénique. Ann. Phytopathol. 5:409-430.

5. Devergne, J. C., and Cardin, L. 1975. Relations sérologiques entre cucumovirus (CMV, TAV, PSV). Ann. Phytopathol. 7:255-276.

6. Devergne, J. C., Cardin, L., Burckard, J., and Van Regenmortel, M. H. V. 1981. Comparison of direct and indirect ELISA for detecting antigenically related cucumoviruses. J. Virol. Methods 3:193-200.

7. Douine, L., Quiot, J. B., Marchoux, G., and Archange, P. 1979. Recensement des espèces végétales sensibles au virus de la mosaique du concombre (CMV) etude bibliographique. Ann. Phytopathol. 11:439-475.

8. Edwards, M. C., and Gonsalves, D. 1983. Grouping of seven biologically defined isolates of cucumber mosaic virus by peptide mapping. Phytopathology 73:1117-1120.

9. Francki, R. I. B., Mossop, D. W., and Hatta, T. 1979. Cucumber mosaic virus. No. 231 in: Descriptions of Plant Viruses. Commonw. Mycol. Inst./ Assoc. Appl. Biol., Kew, England.

10. Garcia-Arenal, F., Alonso-Prados, J. L., Aranda, M. A., Malpica, J. M., and Fraile, A. 1997. Mixed infections and genetic exchange occur in natural populations of cucumber mosaic cucumovirus. Pages 94-99 in: Virus-Resistant Transgenic Plants: Potential Ecological Impact. M. Tepfer and E. Balazs, eds. Springer-Verlag, Berlin.

11. Gonda, T. J., and Symons, R. H. 1978. The use of hybridization analysis with complementary DNA to determine the RNA sequence homology between strains of plant viruses: Its application to several strains of cucumoviruses. Virology 88:361-370.

12. Haase, A., and Rabenstein, F. 1988. Serotype-specific monoclonal antibodies against two cucumoviruses. Arch. Phytopathol. Pflanzenschutz 2: 167-169.

13. He, X., Liu, S., and Perry, K. L. 1998. Identification of epitopes in cucumber mosaic virus using a phage-displayed random peptide library. J. Gen. Virol. 79:3145-3153.

14. Hsu, H. T., Aebig, J., and Rochow, W. F. 1984. Differences among monoclonal antibodies to barley yellow dwarf viruses. Phytopathology 74:600605.

15. Hsu, H. T., Vongasitorn, D., and Lawson, R. L. 1992. An improved method for serological detection of cymbidium mosaic potexvirus infection in orchids. Phytopathology 82:491-495.

16. Hsu, H. T., Wang, Y. C., Lawson, R. H., Wang, M., and Gonsalves, D. 1990. Splenocytes of mice with induced immunological tolerance to plant antigens for construction of hybridomas secreting tomato spotted wilt virus-specific antibodies. Phytopathology 80:158-162.

17. Hsu, Y. H., Lin, F. Z., Hu, C. C., and Yin, S. C. 1989. Host reaction, serology and RNA pattern of cucumber mosaic virus isolates. Plant Prot. Bull. 31:51-59.

18. Kaper, J. M., and Waterworth, H. E. 1977. Cucumber mosaic virus associated RNA 5: Causal agent for tomato necrosis. Science 196:429-431.

19. Kaper, J. M., and Waterworth, H. E. 1981. Cucumoviruses. Pages 257332 in: Handbook of Plant Virus Infections. E. Kurstak, ed. North Holland Biomedical Press, Amsterdam.

20. Maeda, T., Mitsuhata, K., and Inouye, N. 1996. Close relationship between serotype and pathogenicity of cucumber mosaic virus. Bull. Res. Inst. Biores. Okayama Univ. 4:175-185.

21. Owen, J., and Palukaitis, P. 1988. Characterization of cucumber mosaic virus. I. Molecular heterogeneity mapping of RNA 3 in eight CMV strains. Virology 166:495-502.

22. Palukaitis, P., Roossinck, M. J., Dietzgen, R. G., and Francki, R. I. B. 1992. Cucumber mosaic virus. Adv. Virus Res. 41:281-348.

23. Perry, K. L., Habili, N., and Dietzgen, R. G. 1993. A varied population of cucumber mosaic virus from peppers. Plant Pathol. 42:806-810.

24. Piazzolla, P., Diaz-Ruiz, J. R., and Kaper, J. M. 1979. Nucleic acid homologies of eighteen cucumber mosaic virus isolates determined by competition hybridization. J. Gen. Virol. 45:361-369.

25. Porta, C., Devergne, J. C., Cardin, L., Briand, J. P., and Van Regenmortel, M. H. V. 1989. Serotype specificity of monoclonal antibodies to cucumber mosaic virus. Arch. Virol. 104:271-285. 
26. Rist, D. L., and Lorbeer, J. W. 1989. Occurrence and overwintering of cucumber mosaic virus and broad bean wilt virus in weeds growing near commercial lettuce fields in New York. Phytopathology 79:65-69.

27. Rizos, H., Gunn, L. V., Pares, R. D., and Gillings, M. R. 1992. Differentiation of cucumber mosaic virus isolates using the polymerase chain reaction. J. Gen. Virol. 73:2099-2103.

28. Singh, Z., Jones, R. A. C., and Jones, M. G. K. 1995. Identification of cucumber mosaic virus subgroup I isolates from banana plants affected by infectious chlorosis disease using RT-PCR. Plant Dis. 79:713-716.
29. Wahyuni, W. S., Dietzgen, R. G., Hanada, K., and Francki, R. I. B. 1991. Serological and biological variation between and within subgroup I and II strains of cucumber mosaic virus. Plant Pathol. 41:282-297.

30. Waterworth, H. E., Kaper, J. M., and Tousignant, M. E. 1979. CARNA 5 , the small cucumber mosaic virus-dependent replicating RNA, regulates disease expression. Science 204:845-847.

31. White, P. S., Morales, F., and Roossinck, M. J. 1995. Interspecific reassortment of genomic segments in the evolution of cucumoviruses. Virology 207:33-47. 